\title{
THE INFLUENCE OF PERSONAL FACTOR, PARENTAL SUPPORT AND PERCEIVED VALUE OF CHILDREN ON EARLY MARRIAGE IN TROWULAN SUBDISTRICT MOJOKERTO REGENCY
}

\author{
Rina Widiyawati1 ${ }^{1}$, RB Soemanto ${ }^{2)}$, Ety Poncorini Pamungkasari3) \\ 1)Masters Program in Public Health, Sebelas Maret University \\ 2)Faculty of Social and Political Sciences, Sebelas Maret University \\ 3)Faculty of Medicine, Sebelas Maret University
}

\begin{abstract}
Background: According to United Nations Development Economic and Social Affairs, Indonesia is $37^{\text {th }}$ country in the world and $2^{\text {nd }}$ in Southeast Asia after Cambodia with high percentage of early marriage. World Health Organization expects Indonesian government to be more committed to decrease maternal and infant mortality rates as the impacts of early marriage. This study aimed to discover the influence of personal factor, parental support and perceived value of children on early marriage in Trowulan Subdistrict Mojokerto Regency.

Subjects and Method: This was an analytic observational study with case control design. Subjects were women of reproductive age as case (married at the age of $\leq 20$ ) and control (married at the age of 21-25), each consisted of 60 women. The dependent variable was early marriage and the independent variables were levels of education, premarital sexual behavior, perceived behavioral control, perceived benefits, parental support and perceived value of children. The data were analyzed by path analysis.

Results: Perceived behavioral control $(b=-1.27 ; 95 \% \mathrm{CI}=-2.20$ to $-0.33 ; \mathrm{p}=$ o.008), perceived benefits $(b=-1.06 ; 95 \% \mathrm{CI}=-1.97$ to $-0.16 ; \mathrm{p}=0.020)$, parental support $(\mathrm{b}=-1.28 ; 95 \% \mathrm{CI}=-2.16$ to $-0.39 ; \mathrm{p}=0.005)$ and perceived value of children $(b=-2.94 ; 95 \% \mathrm{CI}=-5.20$ to $-0.68 ; \mathrm{p}=0.011)$ had direct influence on early marriage and were statistically significant. The levels of education had indirect influence on early marriage based on the figures of perceived behavioral control $(b=0.92 ; 95 \% \mathrm{CI}=0.17$ to $1.68 ; \mathrm{p}=0.016)$ and perceived benefits $(b=1.31 ; 95 \% \mathrm{CI}=-0.53$ to $2.17 ; \mathrm{p}=0.001)$. Sexual behavior was influenced by perceived behavioral control $(b=1.35 ; 95 \% \mathrm{CI}=0.52$ to 2.17; $\mathrm{p}=0.001$ ).

Conclusion: Early marriage is influenced by perceived behavioral control, perceived benefits, parental support and perceived value of children. Levels of education influence early marriage based on perceived behavioral control and perceived benefits. Premarital sexual behavior is influenced by perceived behavioral control.
\end{abstract}

Keywords: Personal factor, parental support, perceived value of children, early marriage

Correspondence: Rina Widiyawati. Masters Program in Public Health, Sebelas Maret University, Jl. Ir. Sutami 36 A, Surakarta 57126, Central Java, Indonesia. Email: gugik.rina@gmail.com. Mobile: +6282330233064. 